\title{
Ten minutes with Professor Catherine Stoddart, Chief Executive Officer, Northern Territory Health, Australia
}

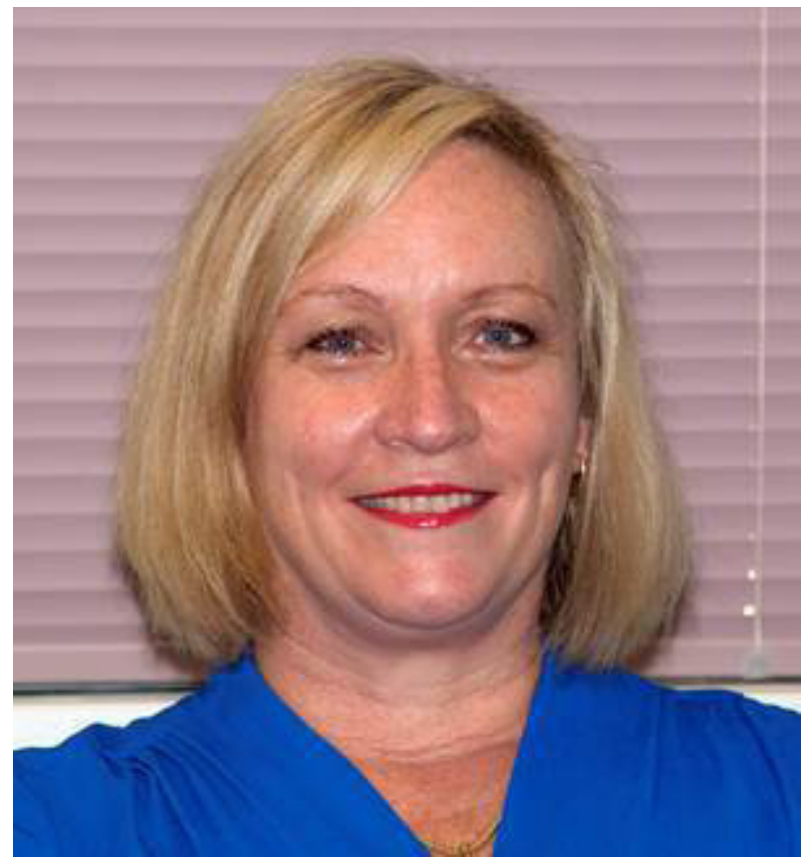

FIRST AND FOREMOST, ARE THERE ANY KEY LEADERSHIP MESSAGES YOU WANT TO GET OUT TO OUR READERSHIP?

As leaders, one of the hardest things to do at this time is to find enough mental space to maintain resilience. Leaders can work all the hours that God gives, but that will not serve our organisations well in the long run. This is a 6-month marathon and we need keep balance and maintain our resilience.

\section{TELL US A LITTLE BIT ABOUT YOUR LEADERSHIP ROLE AND HOW IT IS CHANGING AS A RESULT OF THE PANDEMIC?}

As the chief executive officer (CEO) of Northern Territory Health, I am effectively the head of the Department of Health and of the state-funded provider healthcare organisations (so in UK terms, the Trusts) for the Northern Territory. We are an organisation with approximately 8000 staff serving a population of 240000 people across 1.3 million square kilometres, so we are small, but have a lot of breadth. We provide care for a very, very vulnerable community-in fact, $30 \%$ of our population are aboriginal people, with significantly lower life expectation than non-aboriginal people.

It is not so much my role that is having to change as my leadership style. In the context of the pandemic-and I think this is probably happening to leaders all over the world-I am having to increase the amount of command-and-control, directive leadership I use. Where previously I would have expected to have extensive consultation and discussion with consensus decisionmaking, I find I have to be much more directive in the current environment because of the pace at which things are moving. Most people recognise that there is a crisis and so are receptive to this-they recognise the need for, and appreciate getting, a strong sense of direction, calmness and predictability. This does not mean that behind the scenes, as leader, I am not feeling the burden of what I am dealing with, from time to time; but you cannot waver on decision-making, you need to pause maybe, but

\section{Biography}

Professor Catherine Stoddart, Chief Executive Officer, Northern Territory Health, commenced with the Department of Health in March 2017 and was previously the Deputy Chief Nurse, and Deputy Chief Executive, at the Oxford University Hospitals NHS Foundation Trust (in the UK) from March 2014. She has more than 20 years' experience in executive positions and is a Nuffield Fellow (2000) and Churchill Fellow (2006). Her interest is improving the lives of vulnerable groups of people and has been the focus of many of her roles.

She is a Visiting Professor of Nursing at Oxford Brookes University and was awarded the 2011 Telstra Western Australia Business Woman of the Year for leadership and development of aboriginal employment programmes across Health. In September 2013, she received the Australian Public Service Medal in recognition of her contribution to health and innovative global community health volunteering programmes.

Catherine is an avid dog lover and renovator, and is once again a student.

then you have to get on and take the decisions, changing them as needed.

\section{WHAT EVENTS IN YOUR PAST EXPERIENCE ARE MOST INFORMING YOUR LEADERSHIP IN THIS PANDEMIC?}

Having the background of being a clinician-a nurse-has made a difference; I hope my team, ministers and colleagues feel confident that I understand the issues and the context. I have been exposed regularly to our responses to cyclones, which are common in this part of the world, but do not play out on such a prolonged scale. And my time in Oxford has been a helpful influence in making sure that our governance processes are sound. Everything is changing rapidly; we are making quick decisions, changing models of care and organisational systems rapidly, and the fundamental understanding of governance and risk that I got from the National Health Service (NHS), while in the UK, has been invaluable. There are some elements of the UK regulatory process that I found burdensome, and that are just not suitable for the environment in Australia. What is more they are not agile enough to be helpful in the pandemic. I have decided to take the best elements of governance from my time in the NHS, and that has been very useful.

\section{WHAT ARE YOU FINDING THE BIGGEST CHALLENGES?}

Capacity and capability are big issues; we are a small wholehealth system in a large jurisdiction. We have a huge workforce challenge here in the Northern Territory, as people come for a while, but not so many stay long term. Probably a bigger issue for us in the uncertainty; how long will all this go on? People are used to having natural crises here from cyclones; used to bunkering down, being unable to go outside, but for a short period of time. The uncertainty of this crisis is difficult for leaders and for people looking to leaders for confidence. 


\section{ANY PARTICULAR SURPRISES?}

I do not know if it is a surprise, or about turning crisis into opportunity...but we are seeing transformational changes happen, real fundamental disruption, with great speed, being led by clinicians at a pace, and in a way, they might not previously have tolerated. For example, our default now, for all consultations, is via telehealth. The clinicians are driving this, but we would previously have had to go through a lot of consultation and discussion to make it happen.

We are also seeing changes in funding mechanisms, to allow professions other than doctors-pharmacists, nurses, physiotherapists - to see patients in various ways and be reimbursed for this. That would previously have required a lot of negotiation and probably had colleges and unions involved...instead it is just happening. The past barrier that existed, with Medicare predominantly only providing funding to doctors, has gone.

The other thing I am seeing is that where there are multiple health providers in an area, we are seeing much more collaboration and sharing, in emergency management and clinician rosters. It is not that before the pandemic, the change would not have happened eventually, but it is happening much faster. I think it is creating an energy, and an empowerment of clinicians because they know we are not going to stop them-in fact, we are going to support them in driving change.

\section{ARE YOU SEEING ANY BEHAVIOURS FROM COLLEAGUES THAT ENCOURAGE OR INSPIRE YOU?}

I am seeing cross-agency working across the whole of government, not just in health but education and other sectors. All the CEOs of all the government agencies are meeting 2-3 times a week and we-and our agencies-are working together more to solve problems in collaborative ways. ${ }^{1}$ An example would be how we are supporting our most vulnerable people in terms of finding housing, providing mobile healthcare; it is great to see new joint working, with, say the health and care professional checking on temperature and health status right alongside the welfare worker addressing food and housing issues. It is great to see increased understanding of the importance of the social and environmental determinants of health.

\section{HOW ARE YOU MAINTAINING KINDNESS AND COMPASSION?}

This can be difficult when you are physically exhausted and trying to change your leadership style! In my team, we have invented a light-hearted game as a way to find out how colleagues are doing; we ask each other 'what is your 'COVID-name' today?' This is made up from how you are feeling today and what you had for breakfast. So today, my name is Cheery Hashbrown! It is a simple way for people to be able to name how they feel so the group can understand immediately. One of my colleagues said she was spinning, because she felt she just could not think quickly enough. On a serious note, I think what is really important is how you maintain the human connection. I have already said I do a lot more command-and-control leading, but you have to have a foundation of connection with people. One idea that I think is working is to do a video briefing every week, reminding people to take time for, and care of, themselves, recognising they have personal pressures outside work, for example with elderly parents and/ or young children that they are worried about. There is something about people seeing leaders as having the same trials and tribulations as everyone else; it increases your relatability, but also reduces stress on people because they see that we are all in it together. It can mean sharing some of the worries but I think this is balanced with the reassurance that despite it all, we can get through this. Our motto for the COVID-19 response? Together we can.

\section{ARE THERE ANY IDEAS OR READINGS THAT YOU FIND HELPFUL FOR INSPIRATION AND SUPPORT THAT YOU WOULD RECOMMEND TO OTHERS?}

I would have to say BMJ Leader, of course! Although to be honest, as much as I would like to, I am not getting to the leadership journals at the moment, there just is not the time. But I do think it is important for a leader, a clinical leader in particular, to have a good contemporary understanding of what the clinical issues are. I have been using a lot of WHO documents for that, because they are a reliable source of truth; one of my tasks is to brief government and the opposition very regularly, so I need to be well-informed myself. And Twitter is my friend, because I can get a snapshot of everything in 5 min flat...but you have to be discerning about your Twitter feeds!

\section{WHAT ARE YOU LOOKING FOR FROM YOUR LEADERS?}

In these times, I have valued leaders who are calm and considered in their responses, and are ultimately comfortable making decisions in ambiguity. I think that I follow a leader in times of crisis who has the balance of caution and optimism, a bold approach. ${ }^{2}$ The other aspect that has been really inspiring in colleagues has been where they are seizing the crisis for innovation and improvement.

Thank you for the chance to share my thoughts at this very important time in our history. It has given me a time to reflect, consider my leadership style and area of improvement but remind myself of just how personally and professionally grateful I am.

Catherine Stoddart, ${ }^{1}$ Anthony Berendt ${ }^{2}$

${ }^{1}$ Department of Health, Northern Territory Health, Casuarina, Northern Territory, Australia

${ }^{2}$ Oxford, UK

Correspondence to Dr Anthony Berendt, Oxford, UK; a.berendt@ntlworld.com

Twitter Anthony Berendt @tony_berendt

Funding The authors have not declared a specific grant for this research from any funding agency in the public, commercial or not-for-profit sectors.

Competing interests None declared.

Patient consent for publication Not required.

Provenance and peer review Not commissioned; internally peer reviewed.

Data availability statement No data are available.

(c) Author(s) (or their employer(s)) 2020. No commercial re-use. See rights and permissions. Published by BMJ.

$$
\text { Check for updates }
$$

To cite: Stoddart C, Berendt A. BMJ Leader 2020;4:92-93

Received 9 April 2020

Accepted 14 April 2020

Published Online First 22 April 2020

BMJ Leader 2020:4:92-93.

doi:10.1136/leader-2020-000258

\section{REFERENCES}

1 Lai AY. Organizational collaborative capacity in fighting pandemic crises: a literature review from the public management perspective. Asia Pac J Public Health 2012;24:720.

2 Gates B. Shattuck lecture innovation for pandemics. The New England Journal of Medicine 2018;378:2057-60. 